\title{
Aerobic Degradation of Tributyltin Chloride and Dip-Henyltin Chloride by Marine Bacteria from Onne Port Nigeria
}

\section{Ebah EE* and Ichor T}

Department of Biological Sciences, University of Agriculture Makurdi, PMB 2373, Benue State, Nigeria

\begin{abstract}
Background: Marine bacteria have demonstrated its capability for degradation of organometals including tributyltin chloride and diphenyltin chloride previously. Tributyltin chloride has been used as antifouling paints for boats and it is toxic to aquatic life. Biodegradation of tributyltin chloride and diphenyltin chloride by marine bacteria was monitored for a period of 56 days. Sediment samples were divided into five treatments and impacted with $3.0 \mathrm{mM}$ of tributyltin chloride and diphenyltin chloride respectively. Sediment samples were also amended with $20 \mathrm{~kg}$ of NPK $(20: 15: 15)$ and the rate of degradation was determined using X-ray fluorescence spectrophotometer. Isolates were screened by a medium containing $1.0 \mathrm{~g}$ of $\mathrm{K}_{2} \mathrm{PO}_{4}, 1.0 \mathrm{~g}$ of $\mathrm{KH}_{2} \mathrm{PO}, 1.0 \mathrm{~g}$ of $\left(\mathrm{NH}_{4}\right)_{2} \mathrm{SO}_{4}, 0.4 \mathrm{MgCl}_{2}, 0.125 \mathrm{~g}$ of yeast extract and $1.0 \mathrm{ml}$ of glycerol per liter and $3.0 \mathrm{mM}$ of tributyltin chloride(TBTCl) and diphenyltin chloride (DPTCl) respectively.

Results: Molecular identification of the isolates using DNA sequencing performed by next generation sequence technique was implicated Pseudomonas fluorescens (JX), Pseudomonas aeruginosa (On7), Bacillus subtilis (Py79), Proteus mirabilis (TL3165), Serratia mercescens (PS-1-1), Providencia vermicola (CU12) and Lysinibacillus sphaericus (C5) in the degradation of tributyltin chloride (TBTCl) and diphenyltin chloride (DPTCl).

Conclusion: The study has harnessed the capability of resident aerobic bacteria in marine environment to degrade tributyltin chloride and diphenyltin chloride. The treatments with NPK degraded more compared to the unamended treatments. There was no significant difference between the treatments and the days of degradation ( $p \geq 0.05$ ). Biostimulation or nutrient amendmen therefore should be recommended for the degradation of toxicants such as tributyltin chloride and diphenyltin chloride.
\end{abstract}

Keywords: Marine bacteria; Biodegradation; Environment

Abbreviations: Kg: kilogram; NPK: Nitrogen Phosphorus and Potassium; TBTCl: Tributyltin Chloride; TBT: Tributyltin; CFU/g: Colony Forming Units per Gram; DPTCl: Diphenyltin Chloride.

\section{Introduction}

Tributyltin chloride has been used extensively for various industrial purposes such as antifouling paints for boats, wood preservatives, biocide and as polyvinyl chloride (PVC) stabilizer [1-3]. The efficiency with which a boat moves through water depends on the smoothness of its hull. Increasing the average hull roughness by only $10 \mu \mathrm{m}$ can increase fuel consumption by as much as $1 \%$. If barnacles are present on the hull, they can increase the roughness by several centimeters. Therefore, boats which operate in marine or estuarine waters are coated with antifouling paints. The use of tributyltin as antifouling agents in marine paint formulation has been considerably increased mainly due to its longer resilience, high efficiency and reasonable cost. It prevents the attachment of barnacles and slime on boats and naval ships [4]. This compound have been introduced into aquatic system by means of leaching from the antifouling paints and run off from agricultural fields [5-7]. Tributyltin is one of the mainly toxic substances to aquatic life. Its toxicity is acknowledged to cause harmful effects on a variety of marine living organism such as endocrine disruption, impairment in cell growth, cell distortion and imposex growth and reproduction, influence on the shell, fishery, hurt algal photosynthesis which could also sanction adverse effects in diverse organism from snails to mammals $[8,9]$. Recent studies showed that the application of tributyltin in antifouling agents has been restricted in many countries but their compounds have continued to be detected due to its persistence in the environment $[10,11]$. Microorganisms play important roles in degrading tributyltin. Tributyltin tolerant microorganism strains from genus Pseudomonas among others have been reported [12,13]. Onne port in Nigeria is one of the very busy ports in the country handling a lot of cargoes. It serves as a hub for oil and gas operations. It has a ship yard where ships are packed. Due to the shipping activities of this port, it is susceptible to tributyltin pollution, hence the need to determine the capacity of resident bacteria for its biodegradation.
The aim of this study was to isolate, identify marine organisms and screen them for the degradation of organotin., one of the most toxic substance to aquatic life.

\section{Methods}

\section{Description of the sampling site}

Sediment samples used for this study were collected from Onne sea port, Rivers State, Nigeria. Onne port is located in the southern zone of Nigeria where many ships anchor. It is located on Oguceek near the Bonny River $19 \mathrm{~km}$ from Port Harcourt. It cuts across three local government areas of Rivers State, Eleme, Ogu-Bolo and Bonny. The port consists of two major facilities, the federal ocean terminal and designated as an oil and gas free zone by the Nigeria government. It is a hub for oil and gas operations.

\section{Chemicals}

All chemicals were used without additional purity. TBTCL (96\% purity) and DPTCL (96\% purity) were obtained from sigma-Aldrich chemical company Germany.

\section{Collection of samples}

Sediment samples were collected from a depth of $10 \mathrm{~m}$ from the surface from 15 different points with an Eckman grab (wild life supply

${ }^{*}$ Corresponding author: Ebah EE, Department of Biological Sciences, University of Agriculture Makurdi, PMB 2373, Benue State, Nigeria, Tel: +23444533204; E-mail: ebahesther23@gmail.com

Received June 28, 2018; Accepted July 26, 2018; Published July 31, 2018

Citation: Ebah EE, Ichor T (2018) Aerobic Degradation of Tributyltin Chloride and Dip-Henyltin Chloride by Marine Bacteria from Onne Port Nigeria. J Environ Anal Toxicol 8: 582. doi: 10.4172/2161-0525.1000582

Copyright: @ 2018 Ebah EE, et al. This is an open-access article distributed under the terms of the Creative Commons Attribution License, which permits unrestricted use, distribution, and reproduction in any medium, provided the original author and source are credited. 
Citation: Ebah EE, Ichor T (2018) Aerobic Degradation of Tributyltin Chloride and Dip-Henyltin Chloride by Marine Bacteria from Onne Port Nigeria. J Environ Anal Toxicol 8: 582. doi: 10.4172/2161-0525.1000582

Page 2 of 5

Co. $\mathrm{Ng}$ ) into a sterile polyethene bags and transported immediately to the Microbiology laboratory for analysis.

\section{Experimental set up}

The sediment samples were homogenized and divided into 5 treatments labeled as A, B, C, D and E. Treatment A, B, C was amended with NPK (20:15:15), treatment $D$ was heat treated and treatment $E$ left in its natural state. These treatments were prepared in triplicate and listed as follows:

Treatment A: $30 \mathrm{mM} \mathrm{TBTCl}+20 \mathrm{~g} \mathrm{NPK}+1 \mathrm{~kg}$ Sediment+1000 ml sea water

Treatment B: $3.0 \mathrm{mM} \mathrm{DPTCl}+20 \mathrm{~g} \mathrm{NPK}+1 \mathrm{~kg}$ Sediment+1000 ml sea water

Treatment C: $1.5 \mathrm{mM}$ TBTCl$+1.5 \mathrm{~mm}+20 \mathrm{~g}$ NPK $+1 \mathrm{~kg}$ Sediment+ $1000 \mathrm{ml}$ sea water

Treatment D: $3.0 \mathrm{mM} \mathrm{TBTCl}+1 \mathrm{~kg}$ of heat treated Sediment +1000 $\mathrm{ml}$ sea water

Treatment E: $3.0 \mathrm{mM} \mathrm{TBTCl}+1 \mathrm{~kg}$ sediment as control.

Treatment options were stirred manually twice a day for proper aeration and sampling was done on day 0,28 , and 56 for analysis respectively.

\section{TBTCl and DPTCl degradation using the X-ray fluorescence spectrophotometer}

Degradation of toxicants was obtained by measuring the decrease in the concentration of TBTCl and DPTCl by an X-ray fluorescence spectrophotometer. During the degradation assay TBTCl and DPTCl treated sediments were analyzed on day 0,28 and 56 as decreased concentrations which is the function of the X-ray intensity was recorded accordingly.

\section{Isolation of TBTCl and DPTCl degrading organisms}

Sediment samples from the five treatments were cultured by serial dilution on succinate glycerol (SG) medium. The solution was adjusted to $\mathrm{pH} 6.8$ by adding the required volume of $2 \mathrm{~N} \mathrm{NaOH}$ prior to sterilization. These cultures were sub-cultured to obtain pure cultures.

\section{Screening of bacterial isolates}

Selection of TBTCl and DPTCl degrading bacteria was carried out using a medium that contained: $1.0 \mathrm{~g}$ of $\mathrm{K}_{2} \mathrm{KPO}_{4}, 1.0 \mathrm{~g}$ of $\mathrm{KH}_{2} \mathrm{PO}_{4}$, $1.0 \mathrm{~g}$ of $\left(\mathrm{NH}_{4}\right)_{2} \mathrm{SO}_{4}, 0.4 \mathrm{~g} \mathrm{MgCl}_{2}, 0.125 \mathrm{~g}$ of yeast extract and $1.0 \mathrm{ml}$ of glycerol per liter and $3.0 \mathrm{~mm}$ of TBTCl and DPTCl respectively. The concentration of TBTCl and DPTCl used for the screening were 5, 7 and $10 \mathrm{mM}$ respectively. Cultures were aerobically grown in the dark at $28^{\circ} \mathrm{C}$ [14].

\section{Biochemical/Identification of TBTCl and DPTCl degrading bacterial}

Screening bacteria Isolates capable of utilizing TBTCL and DPTCL were identify and characterized using biochemical tests such as Oxidase, Citrate utilization, Catalase, Indole production, triple sugar Iron Utilization Methly red, Voges Postaver, Glucose fermentation, Urease Production, Gram stain and Motility test as described by Fukagawa et al. [15].

\section{DNA sequencing}

DNA sequencing was performed by next generation sequencing technique to determine the nucleotide sequence of all microorganisms present in the soil sample using automated PCR Cycle-genome Sequence TM FLX system for 454 life science TM and Roche applied. The $16 \mathrm{~S}$ rRNA gene was used. Sequence analysis and alignment was performed using vector NTL suite 9 (Infor Max, Inc). And the resulting nucleotide sequences obtained from Gen-Bank [16].

\section{Results}

Degradation of TBTCl and DPTCl by bacteria was monitored. The result showed that treatment A (Figure 1) showed a reduction in concentration of TBTCl from $382 \mathrm{mg} / \mathrm{kg}$ on day 0 to $10.1 \mathrm{mg} / \mathrm{kg}$ on day 56 . The bacteria grew exponentially during the period monitored but decreased gradually toward the $56^{\text {th }}$ day. This was observed in all treatments though the level of reduction varied. Microbial response occurred in all the treatments, but their level of reduction varied. Treatment B (Diphenyltin chloride in sediment amended with NPK) also demonstrated a decline in concentration from $382 \mathrm{mg} / \mathrm{kg}$ on day 0 to $20.5 \mathrm{mg} / \mathrm{kg}$ on day 56 . Treatment C (Tributyltin chloride+diphenyltin chloride in sediment $+\mathrm{NPK}$ ) also showed a decrease in concentration from $382 \mathrm{mg} / \mathrm{kg}$ on day 0 to $104.8 \mathrm{mg} / \mathrm{kg}$ on $56^{\text {th }}$ day. Treatment E had sediment and tributyltin chloride without nutrient amendment. The concentration reduced from $382 \mathrm{mg} / \mathrm{kg}$ on day 0 to $115.3 \mathrm{mg} /$ $\mathrm{kg}$ on day 56. Treatment $\mathrm{D}$ showed a decline in the concentration of tributlytin chloride, from $382 \mathrm{mg} / \mathrm{kg}$ on day 0 to $106.6 \mathrm{mg} / \mathrm{kg}$ on day 56. The result in all the treatment was not statistically significant except for treatment $\mathrm{E}$ which had no nutrient amendment. The degradation of TBTCl could be attributed to the activity of abiotic factors such as sunlight and it was also possible that the scanty growth observed on day 28 and 56 were assumed to be contaminants which possessed inherent degradation traits in them. This was likely responsible for the reduced concentration of TBTCl observed in treatment D. Degradation activity seen in treatment $\mathrm{E}$ (controlled treatment) was attributed to the activity of authouchtonous microbes. Organisms here utilized TBTCl hence a reduction. An observed reduction in treatment options A, B and C was attributed to the action of the bacterial cells that were busted up by the effect of the nutrient amendment (NPK). The degradation activity in $\mathrm{A}, \mathrm{B}$, and $\mathrm{C}$ were higher than that of treatment $\mathrm{D}$ and $\mathrm{E}$, as shown in Figures 1-5.

The metabolites of tributyltin chloride degradation include aliphates, hydrocarbons and little amount of the test compound itself (tributyltin chloride). The chromatogram is shown on Figure 6.

The identity of the bacteria implicated in the degradation of tributyltin chloride and diphenyltin chloride were confirmed by $16 \mathrm{~S}$ rRNA amplification by polymerase chain reaction (PCR). Sequence analysis and alignment that was performed showed their strain, percentage similarities and the accession number of the bacteria. Their molecular identification is shown in Table 1.

\section{Discussion}

Organotins are present in estuarine environment in appreciable amount where bacterial strains which can tolerate and degrade than get enriched (Wuertz, 1991). The total viable counts of treated sediments from Onne port on nutrient agar and mineral salt agar indicated that approximately $18.5 \%$ of the bacterial population was resistant to 0.1 $\mathrm{mM}$ of TBTCl and DPTCl. This is apparent in this study since the isolates grew on MSA supplemented with TBTCl and DPTCl, utilizing it as a sole source of carbon. The study has shown that bacteria floras of Onne sea port are resistant or can tolerate and degrade TBTCl and DPTCl. This is evident in the reduction in concentration of the test 
Citation: Ebah EE, Ichor T (2018) Aerobic Degradation of Tributyltin Chloride and Dip-Henyltin Chloride by Marine Bacteria from Onne Port Nigeria. J Environ Anal Toxicol 8: 582. doi: 10.4172/2161-0525.1000582

Page 3 of 5

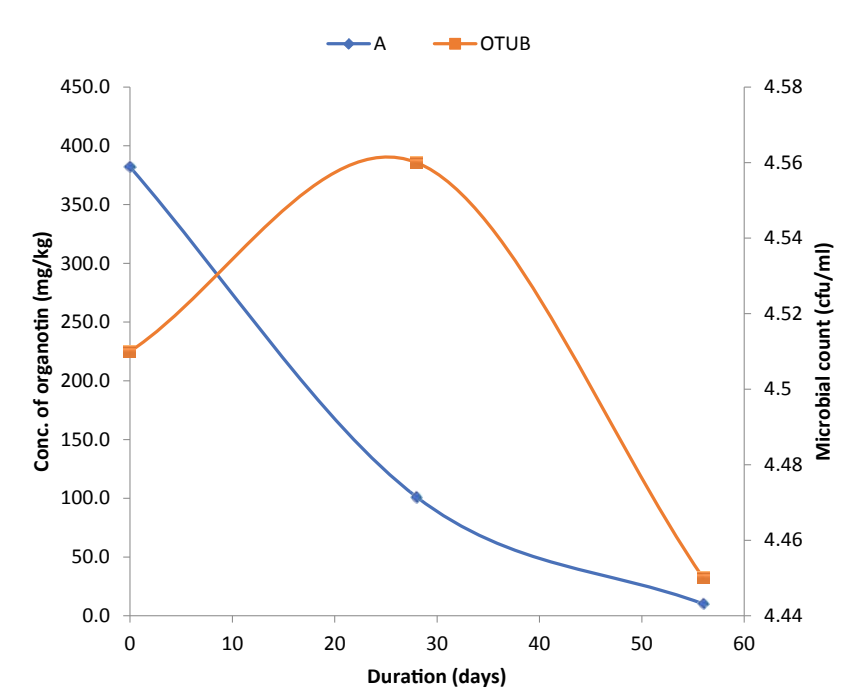

A: Tributyltin chloride+NPK; OTUB: Organotin utilizing bacterial

Figure 1: Microbial utilization of tributyltin chloride+NPK.

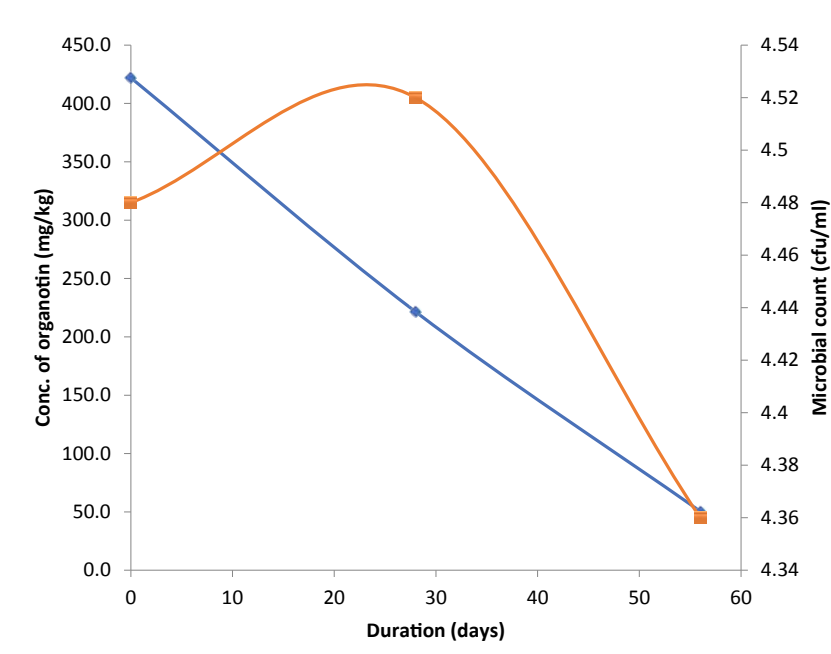

B: Diphenyltin chloride+NPK; OTUB: Organotin utilizing bacterial.

Figure 2: Microbial utilization of diphenyltin chloride+NPK.

chemicals with a corresponding increase in bacterial population at the initial stage of the experiment followed by a gradual decline as the chemicals got exhausted as shown. Similar findings that antifoulants in ship paints, shipyards harbor is considered to be the prime source of TBTCl and that marine bacteria in such sites are TBTCl tolerant [17] corroborate the findings of the present study.

Onne Port is one of the biggest ports in the south region of Nigeria with modern ship repairing systems involved in the repair and construction of commercial and naval ships. During this process, old paint is being blasted out, which finally ends up in to the marine environment where gradually TBT leaches. Chau et al. [18] have demonstrated that heavy contamination of coastal water and sediment by TBT was associated with major commercial harbors and ship repair activities from the hull and application of a new coating which could release TBT in waste water discharge.

There was an obvious reduction in the total viable count from the different treatment used at the course of this present study. The reduction in the total viable count from $4.55 \times 10^{4} \mathrm{cfu} / \mathrm{g}$ to $3.25 \times 10^{4}$ of TBTCl 4.47 to $3.0 \times 10^{4} \mathrm{cfu} / \mathrm{g}$ of DPTCl showed clearly that the bacterial isolates had inherent capability to utilize these chemical as their source of carbon. In this present study, isolates were sub-cultured with increasing concentrations of TBTCl and DPTCl (3.0 mM to 7.0 $\mathrm{mM})$. Out of 97 isolates growing in $3 \mathrm{mM}$ of these chemicals, 7 isolates showed consistent growth in presence of $3 \mathrm{mM}, 5 \mathrm{mM}, 7 \mathrm{mM}$ and 10 $\mathrm{mM}$ with an optimum condition for growth that is temperature at $28^{\circ} \mathrm{C}$, pH 7.8-8.0 and salinity of $2.5-3.5 \%$. This could be attributed to the fact that bacterial isolates from Onne port possess inherent capability to resist and degrade TBTCl and DPTCl.

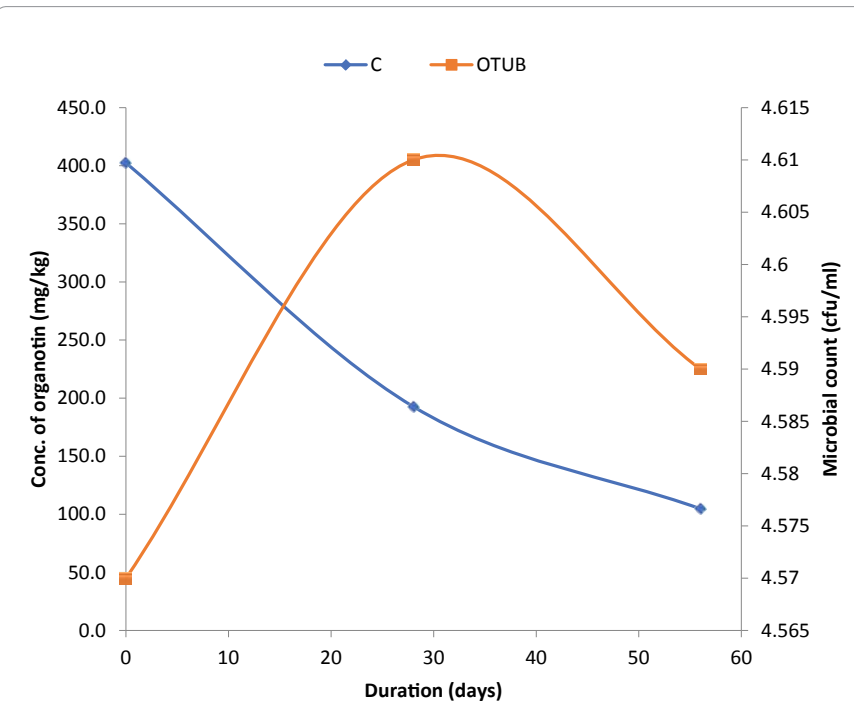

KEY: C: Tributyltin chloride+diphenyltin chloride+NPK; OTUB: Organotin utilizing bacterial

Figure 3: Microbial utilization oftributyltin chloride+diphenyltin chloride+NPK.

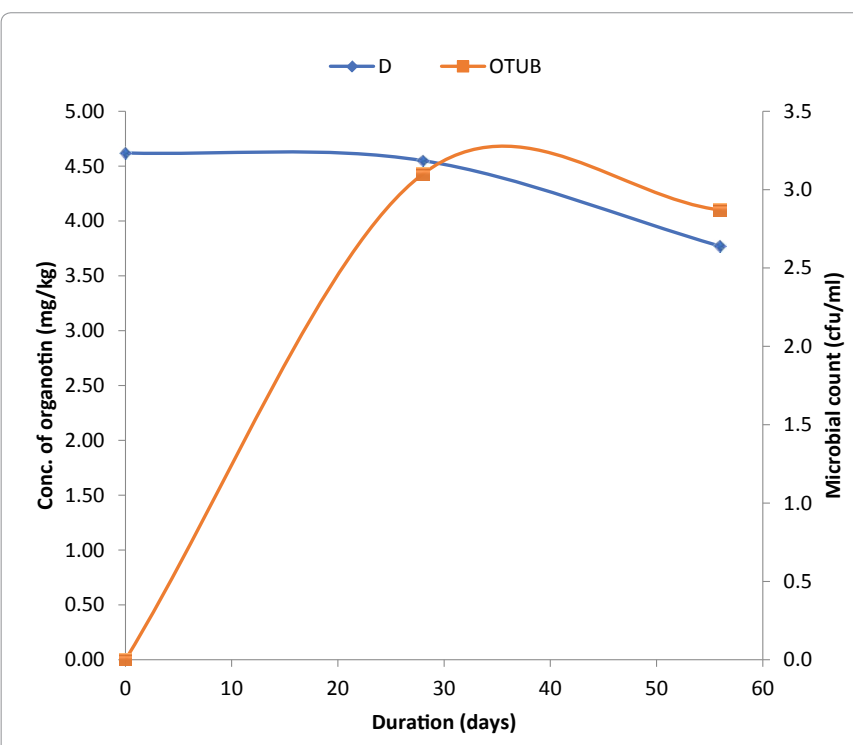

KEY: D: heat treated sediment+tributyltin chloride; OTUB: Organotin utilizing bacterial

Figure 4: Microbial utilization of heat treated sediment+tributyltin chloride. 
Citation: Ebah EE, Ichor T (2018) Aerobic Degradation of Tributyltin Chloride and Dip-Henyltin Chloride by Marine Bacteria from Onne Port Nigeria. J Environ Anal Toxicol 8: 582. doi: 10.4172/2161-0525.1000582

Page 4 of 5

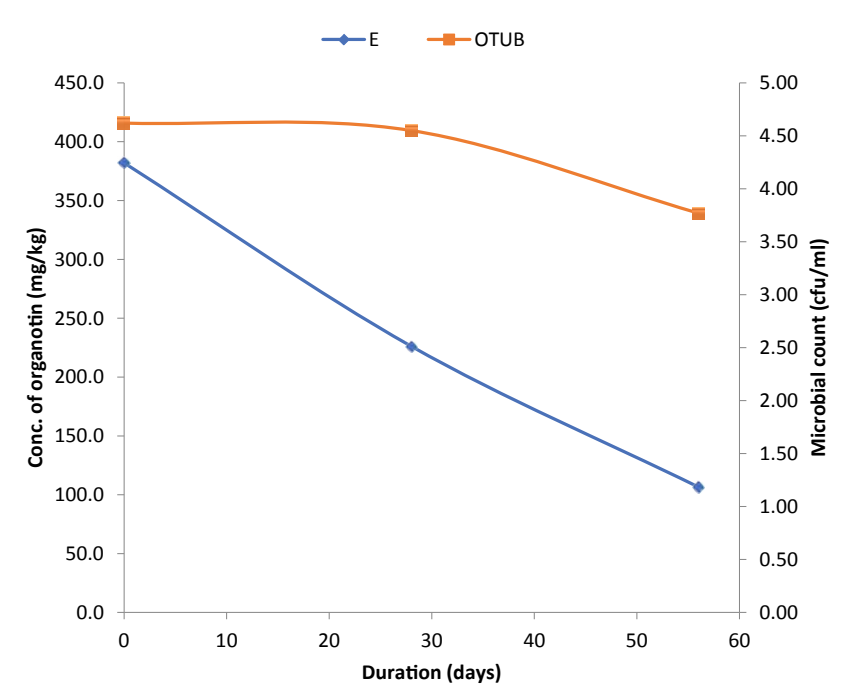

KEY: E: Control sample (sediment+tributyltin chloride); OTUB: Organotin utilizing bacteria

Figure 5: Microbial utilization of sea sediment+tributyltin chloride.

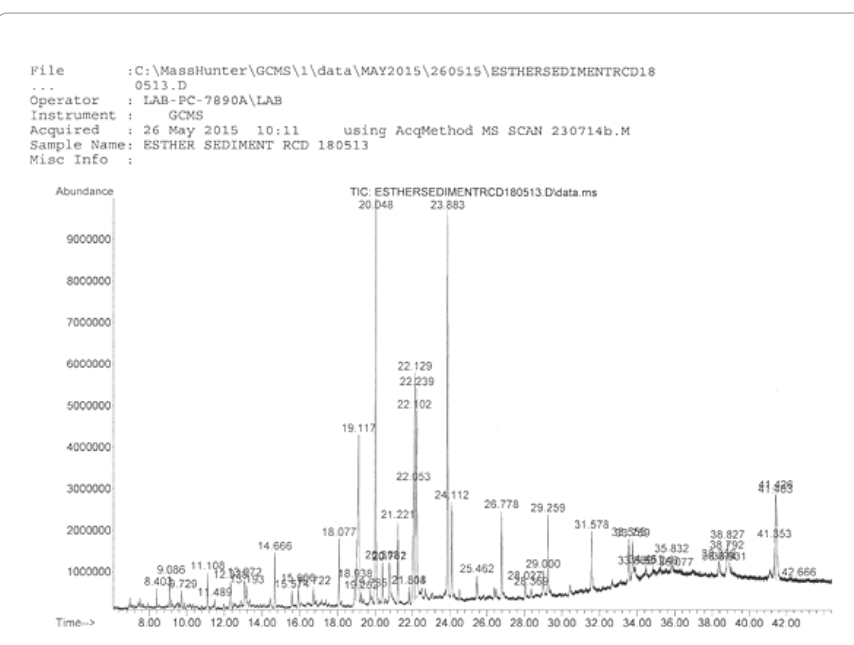

Figure 6: Chromatogram of degradation metabolites.

\begin{tabular}{|c|c|c|c|c|}
\hline S No & Name of organism & Strain & \% Similarity & Accession No. \\
\hline 1 & Pseudomonas fluorescens & JX & 99 & Gu220720.1 \\
\hline 2 & Pseudomonas aeruginosa & On7 & 99 & Hq377326.1 \\
\hline 3 & Bacillus subtilis & Py79 & 100 & CP006881.1 \\
\hline 4 & Proteus mirabilis & TL3165 & 99 & KF051775 \\
\hline 5 & Serratia mercescens & PS-1-1 & 100 & KF258679.1 \\
\hline 6 & Providencia vermicola & CU12 & 100 & KF471514.1 \\
\hline 7 & Lysinibacillus sphaericus & C5 & 98 & KF523303.1 \\
\hline
\end{tabular}

Tributyltin chloride-TBTCl; Diphenyltin chloride-DPTCl; Organotin utilizing bacteriaOTUB

Table 1: Molecular identification of bacteria isolates implicated in degradation of TBTCl and DPTCI.

Although growth of these isolates in DPTCl was not too conspicuous, however few strains grew at a concentration of $5 \mathrm{mM}$. The TBTCl utilizing isolates maintained with $5 \mathrm{mMTBTCl}$ were incubated at $28^{\circ} \mathrm{C}$ a temperature suitable for marine/estuarine samples. Most of the bacterial isolates could not grow in presence of higher concentration of TBTCl (7 mM-10 mM) due to cellular toxicity and inhibitory effect on metabolic process and viability of bacterial strains [19].

Singh et al. [20] reported the range of microbial resistance of up to $0.007 \mathrm{mM}$ for different organotin compounds which agrees with the present studies.

Debutylation of TBT compounds to di- and mono-butyltins is known to occur in bacterial, algae and fungi which provides one route for detoxification of tributyltin. Microorganisms are capable of accumulating TBT compounds, which is another mechanism of removal of TBT from marine environment [21]. The findings of Fukagawa et al. [15] reported that TBTCl tolerant bacterial are present in sea water and sediment and the findings of Suzuki et al. [13] and Ebah et al. [14] reported that Pseudomonas aeruginosa can degrade tributyltin chloride at $2.5 \mathrm{ppm}$ level.

The result of the metabolites of organotin (TBTCl) degradation indicated that at the end of 56 days of degradation process, only $0.96 \%$ of the test chemical was left. The percentage left was quite minimal compared to the initial composition. Other chemical components found in the tested samples include some aliphates and a little content of hydrocarbons. TBT as early as the 1970s was known to be very toxic to many aquatic organisms and the high toxicity of TBT is attributed to its effects on mitochondrial function [22]. The studies of Albalat et al. [23] showed that the degradation of organotins was significantly slower in sterile soils. Non-sterile soils and the metabolites form is either more bioavailable or more toxic that is the parent compound or both. The findings from this study showed a drastic reduction in the percentage concentration which is one of the functions of its toxicity in contrast to previous research findings [23].

\section{Conclusion}

The highly potent isolates identified as Pseudomonas fluorescens JX, Pseudomonas aeruginosa ON 7 and Bacillus subtilis Py 79 tolerating up to $7 \mathrm{mM}-10 \mathrm{mM}$ of TBTCl and growing very well in $5 \mathrm{mM}$ TBTCl could be really very promising in the bioremediation of organotin contaminated marine and estuarine environment. Microorganisms have shown to bioremediate organotin contaminated sites though mediation of the remediation by microbes is far away from real large scale commercial process since very little work has been done to explore the exact biochemical mechanisms of organotin biodegradation and genes involved in the processes. The metabolic pathway of degradation of organotin, TBTCl should be the challenge for further studies. Biostimulation/nutrient amendment is highly advocated for since the rate of degradation was higher compared to the unamended treatment.

\section{Acknowledgements}

We acknowledge the contributions of Prof. GSC Okpokwasili that brought the work to its present standard. The work was funded by the authors. It was not sponsored by any agency.

\section{Availability of Data and Materials}

All the generated and analyzed data during the study are included in the article.

\section{Author's Contributions}

This work was carried out in collaboration between all authors. Author Ebah EE designed the project in collaboration with the co-author. She planned and led the research to execution, analysed data and effected all the corrections as required by the reviewers. Author Ichor $\mathrm{T}$ assisted in the design, execution and also contributed in the literature search and statistical analysis. He is responsible for replying and effecting all corrections as required by the publishers of this article. All authors read and approved the final manuscript. 
Citation: Ebah EE, Ichor T (2018) Aerobic Degradation of Tributyltin Chloride and Dip-Henyltin Chloride by Marine Bacteria from Onne Port Nigeria. J Environ Anal Toxicol 8: 582. doi: 10.4172/2161-0525.1000582

\section{References}

1. Turner A (2010) Marine pollution from antifouling paint particles. Marine Pollution Bulletin 60: 159-171.

2. Gadd GM (1993) Microbial formation and transformation of organometallic and organometalloid compounds. FEMS Microbiology Reviews 11: 297-316.

3. Almeida E, Diamantino TC, de Sousa O (2007) Marine paints: the particular case of antifouling paints. Progress in Organic Coatings 59: 2-20.

4. Gadd GM (2000) Microbial interactions with tributyltin compounds: detoxification, accumulation, and environmental fate. Science of the Total Environment 258: 119-127.

5. Fent K (1996) Organotin compounds in municipal wastewater and sewage sludge: contamination, fate in treatment process and ecotoxicological consequences. Science of the Total Environment 185: 151-159.

6. Pent K, Hunn J (1995) Organotins in freshwater harbors and rivers: temporal distribution, annual trends and fate. Environmental Toxicology and Chemistry 14: 1123-1132.

7. Dowson PH, Bubb JM, Lester JN (1993) Temporal distribution of organotins in the aquatic environment: five years after the 1987 UK retail ban on TBT based antifouling paints. Marine Pollution Bulletin 26: 487-494.

8. Antizar-Ladislao B (2008) Environmental levels, toxicity and human exposure to tributyltin (TBT)-contaminated marine environment. A review. Environmen International 34: 292-308.

9. Meador JP, Rice CA (2001) Impaired growth in the polychaete Armandia brevis exposed to tributyltin in sediment. Marine Environmental Research 51: 113-129.

10. Bellas J, Hilvarsson A, Granmo $\AA$ (2005) Sublethal effects of a new antifouling candidate on lumpfish (Cyclopterus lumpus L.) and Atlantic cod (Gadus morhua L.) larvae. Biofouling 21: 207-216.

11. Barug D (1981) Microbial degradation of bis (tributyltin) oxide. Chemosphere 10: $1145-1154$

12. Jay S, Neelesh D (2011) Bioremediation of organometallic compounds by bacteria. Indian Journal of Microbiology 87: 567-569.
13. Suzuki S, Fukagawa T, Takama K (1992) Occurrence of tributyltin-tolerant bacteria in tributyltin-or cadmium-containing seawater. Applied and Environmental Microbiology 58: 3410-3412.

14. Ebah E, Ichor T, Okpokwasili GC (2016) Isolation and biological characterization of tributyltin degrading bacterial from onne port sediment. Open Journal of Marine Science 6: 193.

15. Fukagawa T, Konno S, Takama K, Suzuki S (1994) Occurrence of tributyltin(TBT) and methyl mercury tolerant bacteria in natural seawater to which TBT was added. Journal of Marine Biotechnology 1: 211-214.

16. Altschul SF, Madden TL, Schaffer AA, Zhang J, Zhang Z, et al. (1997) Blast and PSI-Blast: a new generation of protein data base search programs. Nucleic Acids Research 25: 3389-3402.

17. De Mora SJ, Pelletier E (1997) Environmental tributyltin research: past, present, future. Environmental Technology 18: 1169-1177.

18. Chau YK, Maguire RJ, Brown M, Yang F, Batchelor SP (1997) Occurrence of organotin compounds in the Canadian aquatic environment five years after the regulation of antifouling uses of tributyltin. Water Quality Research Journal 32: 453-522.

19. Pettibone GW, Cooney JJ (1986) Effect of organotins on fecal pollution indicator organisms. Applied and Environmental Microbiology 52: 562-566.

20. Singh K (1987) Frontier in Applied Microbiology. Publication Print House, New Delhi, India 11: 297-316.

21. Ray SA, Ray MK (2009) Bioremediation of heavy metal toxicity-with specia reference to chromium. Al Ameen J Med Sci 2: 57-63.

22. Blaber SJ (1970) The occurrence of a penis-like outgrowth behind the right tentacle in spent females of Nucella lapillus (L.). Journal of Molluscan Studies 39: 231-233.

23. Albalat A, Potrykus J, Pempkowiak J, Porte C (2002) Assessment of organotin pollution along the Polish coast (Baltic Sea) by using mussels and fish as sentinel organisms. Chemosphere 47: 165-171. 